Check for updates

\title{
OPEN Author Correction: Glucocorticoids suppress Wnt16 expression in osteoblasts in vitro and in vivo
}

\section{Susanne Hildebrandt, Ulrike Baschant, Sylvia Thiele, Jan Tuckermann (1), Lorenz C. Hofbauer \& Martina Rauner}

Correction to: Scientific Reports https://doi.org/10.1038/s41598-018-26300-z, published online 07 June 2018

This Article contains an error. The text in Figure 2's legend,

"Bone mineral density (BMD) of the femoral bone was determined by using $\mu \mathrm{CT} \ldots$.."

should read:

"Bone mineral density (BMD) of the femoral bone was determined by using pQCT..."

(c) (i) Open Access This article is licensed under a Creative Commons Attribution 4.0 International License, which permits use, sharing, adaptation, distribution and reproduction in any medium or format, as long as you give appropriate credit to the original author(s) and the source, provide a link to the Creative Commons license, and indicate if changes were made. The images or other third party material in this article are included in the article's Creative Commons license, unless indicated otherwise in a credit line to the material. If material is not included in the article's Creative Commons license and your intended use is not permitted by statutory regulation or exceeds the permitted use, you will need to obtain permission directly from the copyright holder. To view a copy of this license, visit http://creativecommons.org/licenses/by/4.0/.

(c) The Author(s) 2020 